socialization, learning, development, correction, counseling, psychotherapy, follow-up and rehabilitation may be applied to cope with children's emotional deprivation. We consider follow-up to be the most effective and comprehensive method. The psychological follow-up model developed and tested by us includes support provided to foster families in the course of coping with children's emotional deprivation adverse effects and is based on the system of working with foster children and parents, as well as on conducting joint classes involving parents and children. We've applied various psychological correction and development methods (talk, games, exercises, drawing, fantasizing and relaxation) in combination with psychotherapeutic methods (symbol drama, art therapy and positive psychotherapy) to conduct psychological follow-up of children. Effectiveness and efficiency of the emotionally deprived elementary school children psychological follow-up model developed by us has been tested on the ground of repetitive psychodiagnostic testing and comparing its results of control and experimental groups. The application of remedial methods in combination with psychotherapeutic methods has made it possible to obtain constant and long-lasting results in emotional deprivation evidences reducing and elementary school children emotional intelligence level raising.

Keywords: emotional deprivation, elementary school children, emotional deprivation effects, psychological follow-up, psychological correction, psychotherapy, emotional intelligence.

Подано до редакиії 06.04.2021

UDC: $159.923: 159.964 .21$

DOI: https://doi.org/10.24195/2414-4665-2021-2-2

Serhii Dolynnyi, PhD student,

Department of Psychology and Social Work, Vinnitsa State Pedagogical University named after Mikhail Kotsyubinsky, 32, Ostrozhskogo Str., Vinnitsa, Ukraine, ORCID ID: https://orcid.org/0000-0001-7146-6383

\title{
PERSONALITY PSYCHOLOGY IN THE CONTEXT OF CONFLICT INTERPRITATIONS
}

The article analyzes the most important psychological preconditions of a conflict situation on the basis of which the strategy and tactics of people's behavior in case of differences of their interests are formed. The main psychological models of conflict are presented in the study, which is used to interpret sociotypes that highlight the psychological portrait of the individual in the perspective of modernity. The purpose of the study is to substantiate the causal dysfunctions in the implementation of conflict situations and highlight ideas for avoiding conflict demonstrated by the individual. The study used the Keirsey questionnaire to assess the temperament of participants and K. N. Thomas' methodology to determine their typical ways of responding to a conflict situation, which identified the tendency of sociotypes to rivalry and cooperation, the desire for compromise, conflict avoidance and flexibility in decision making. The article considers a concept of personality types and their interaction in the structure of interpersonal relationships. According to the methodology of D. Keirsey, which is based on the typology of Carl Jung and the theory of information metabolism of A. Kempynsky, there are 16 types of information sharing between individuals. The formation of a sensitive image of a person as an adequate information subject characterizes the problem of defining a person's personality in a continuous flow of information, communicative perceptions, innovative competencies and different value systems. Having followed the method of $K$. N. Thomas that is designed to determine the typical ways of individuals' responds to conflict situations, we determine an inclination of the above mentioned sociotypes to competition and cooperation, as well as desire to compromise and avoid conflicts, and flexibility in decision making. In the framework of the Socionic model, the subjects of information influences make adequate assessment of their potential, find appropriate ways of self-realization, competitively and objectively perceive the abilities of others in order to form a harmonious relationship with them. The problem that arises in a conflict always stands in the way of the implementation of goals, which refer to both the interests and fears of person. Barriers that work against the implementation of needs and interests in a conflict are always associated with communication, since other people's activities are often perceived as a dissonance of individual and his/her environment. A mixture of contradictions caused by different types of experience and behavior, character traits and other factors of interpersonal interaction provide the basis of conflict. The conceptual importance of personality covers a wide range of internal mental processes that determine the features of human behavior in different situations. The objective conflict management is the only way that leads to positive dynamics in the conflict of interest, with the main criterion being the ability to compromise, based on the understanding that contradictions can give ground to the development that, in its turn, can bring about effective cooperation.

Keywords: sociotype, personality, conflict situation, conflict management, social group, factors of interpersonal interaction. 


\section{problem}

Introduction and the current state of the research

Modern psychology of personality transforms worldviews about human nature in the concept that identifies it in the dimension of personal existence as a factor in knowing the world. The originality of the individual is only his/her inherent individuality. It can manifest itself in one or several areas of the human psyche. Satisfaction of a person with the consequences of his/her work, position in society, relationships with other people is largely associated with the possibility of development and implementation of individual traits. This explains the need for a detailed study of individual personality traits in the context of conflicts and clashes, disputes and situations of increased discomfort.

The problem of defining personality in a continuous flow of information load, communicative perceptions, innovative competencies, a variety of models of worldview is the formation of a sensory image of person as an informative subject, adequate in the sociometric dimension. This problem at the historical stage of studying the psychology of personality is quite clearly reflected in the theories of S. Freud, K. Jung, A. Adler, A. Maslow, K. Rogers, G. Eisenko, K. Platonov and others. They pointed out that having a variety of properties, personality is a whole. Individualization of personality is due to the presence of consciousness as a specific human reflection of subjective images of the objective world, capable of retaining, storing and exchanging information. Consciousness is a socio-historical product. It arises together with human society in the process of formation and development of labor and language, formed only in a social environment, constant communication between individuals. All this is a very important human ability to understand the environment, to realize their place in society, their actions, feelings, thoughts, interests, etc. (Hong, Choi, Espelage, Boraggina-Ballard \& Fisher, 2020).

\section{Purpose and tasks}

The purpose of the study is to substantiate the causal dysfunctions in the implementation of conflict situations and highlight ideas for avoiding conflict by the individual. The main objective of the research is the study of structural organization sociotypes high conflict personalities and determine its dominant type of behavior in this situation.

\section{Research methods}

The study used the Keirsey questionnaire to assess the temperament of participants and K. N. Thomas' methodology to determine their typical ways of responding to a conflict situation, which identified the tendency of sociotypes to rivalry and cooperation, the desire for compromise, conflict avoidance and flexibility in decision making.

Personality is an abstract concept that combines many aspects that characterize a person: emotions, motivation, thoughts, experiences, perceptions and actions. The conceptual meaning of personality covers a wide range of internal mental processes that determine the characteristics of human behavior in different situations. Theories of personality are very different from each other, so it is almost impossible to simply sum up the conceptual definition of "personality". Within psychology, there is no single common meaning - values as many as psychologists and theories of personality that encourage the solution of this problem. Interests and motives, inclinations and abilities, character and temperament, ideals, values of orientation, volitional, emotional and intellectual features, the ratio of conscious and unconscious (subconscious) in the perspective of modernity highlight the psychological portrait of the individual (Kramarenko, 2016).

\section{Research results}

The experimental study involved 108 students of Vinnytsia State Pedagogical University, who differ mainly in motivational orientation to achieve excellent academic performance.

According to Keirsey method that is designed to determine the typological characteristics of temperament and character of human socialization, we see that the conditionally dominant sociotype of personality is denoted as follows: E - extrovert, I - introvert, S - sensory, $\mathrm{N}$ - intuitive, $\mathrm{T}$ - rationalist, $\mathrm{F}$ - aesthetic, $\mathrm{J}$ - statist, $\mathrm{P}$ - dynamic. Together these types form different combinations that determine a person's professional orientation: ESTJ, ENTJ, ENFJ, ESFJ, ISTJ, INTJ, INFJ, ISFJ, ESTP, ENTP, ENFP, ESFP, ISTP, INTP, INFP, ISFP. Interpretation of the results by this method showed the predominance of such sociotypes as merchant (ESFJ) - 25\% (27 persons), journalist (ENFP) $-21 \%$ (23 persons), philosopher (INFP) - 11\% (12 persons) and conservative (ISFJ) $11 \%$ (12 persons) and 30\% (32 persons), which remained outside our study due to the lack of significant indicators (Viznyuk, 2020).

Table 1

Typical Properties social personality type

\begin{tabular}{|c|l|l|}
\hline Combination and name & \multicolumn{1}{|c|}{ Personal qualities } & \multicolumn{1}{|c|}{ Professionally important quality } \\
\hline ESFJ “Kommersant" & $\begin{array}{l}\text { Prudence, vital courage, wisdom, } \\
\text { buoyancy }\end{array}$ & $\begin{array}{l}\text { Practicality, ability benefit from any } \\
\text { situation, propensity for commerce }\end{array}$ \\
\hline ENFP "Journalist" & $\begin{array}{l}\text { Enthusiasm, optimism, wide erudi- } \\
\text { tion, sensitivity }\end{array}$ & Creative orientation \\
\hline INFP "Philosopher" & $\begin{array}{l}\text { Tendency to search for the meaning } \\
\text { of life, spirituality }\end{array}$ & $\begin{array}{l}\text { Tendency to search for meaning in } \\
\text { the phenomena of nature, human life }\end{array}$ \\
\hline ISFJ "Conservative" & $\begin{array}{l}\text { Calmness, restraint, mastery, punctuality, } \\
\text { self-confidence, a sense of duty }\end{array}$ & $\begin{array}{l}\text { Diligence at work, organization, } \\
\text { planning, prefers clear goals, respon- } \\
\text { sibility, practicality }\end{array}$ \\
\hline
\end{tabular}


The identified features of sociotypes in accordance with this method allowed to obtain information about the factors that determine the behavior and manifestations of mental barriers that cause conflict.

Sociotype "Philosopher" Intuitive and ethical introvert (IEI, INFP)

When making a decision, representatives of this type use creative energy: curiosity, indifference to everything new, unusual, beautiful, fantasy, dreaminess, romanticism, even persistence in requests, if they are driven by a strong desire. They are guided by an individual approach at the time of optimal determination of a person's position, objectively oriented in time space. In addition, in the case of cooperation, they impress with unexpected, sometimes extravagant actions and statements. Appearance is often a source of influence on people. In the interests of business, they are guided by the diplomatic skills and affectation words. Conflict situation is caused by such personal characteristics as increased concentration on the subject of work, tendency to make empty promises, internal vulnerability, contradictions, partial self-doubt, tendency to fluctuate in the choice of decisions, complaints about bad life, suffering, tendency to excessive demands in habitual comfort, skepticism, aggression, etc. In work they show activity, tendency to complicate to details the situational relations; they are detail-oriented and guided by performance of the big range of work, but for lack of time they avoid its realization.

\section{(ESI, ISFJ)}

Sociotype "Conservative" Ethical-sensory introvert

The students of this sociotype proved to be organized, pleasant and reliable performers, focused on selfless cooperation, providing and conducting various leisure activities, rejoicing for others. They are guided by the principles of achieving goals in accordance with clear organizational instructions. They are psychologically resistant to uninteresting, often routine and monotonous work. They perform well in the direction of personal perspectives, but the decision making process depends on the instructions of others. They are willing to help people in difficult times for them, provide a variety of assistance to socially vulnerable groups. The representatives of this sociotype are usually important in the team, as they reconcile the interests of opposing parties, resolve various conflict situations through cooperation and dialogue based on compromise solutions. They objectively unite the team, focusing it on joint activities. Conflict maladaptation of these students is caused by such personal qualities as self-doubt, inability to quickly adapt to change, difficulty in understanding the hidden causes of phenomena, a certain stereotype of thinking; perceive injustice, vulnerable to prejudice biased accusations (Viznyuk, 2020).

Sociotype "Journalist" Intuitive and ethical extrovert (IEE, ENFP)

According to this type, students showed themselves sociable, erudite, charismatic and diplomatic. They have the ability to approach any person, the ability to make compliments, the desire to cooperate, to understand the abilities of others, to feel good about their hidden abilities and shortcomings. Stress-resistant to failure need a con- stant influx of new experiences, innovative information. According to the study, there are $10 \%$ (7 people) of leaders among them who form the team and quickly adapt to it. The tendency to a certain disorganization and impracticality, delays in completing tasks on time, distraction from secondary matters, sometimes poor performance of tasks, lack of systematization of documentation lead to the destruction of interests in interpersonal relationships. Sometimes students of this sociotype lack selforganization and patience in bringing the case to an end. They are quickly disappointed in the objects of their own sympathies, unrestrained, too emotional in conflict situations, even a little aggressive. They seek to control the feelings of others and so on.

Sociotype "Kommersant" Logical-intuitive extrovert (LIE, ESFJ)

The representatives of this sociotype are characterized by curiosity, the ability to comprehend the hidden essence of phenomena, mainly guided by the abstractlogical type of thinking. They have dynamism, mobility, activity, diligence, acute feeling of the passage of time; they do not lag behind. They are well versed in business activities, interested in useful things and in the latest technologies that can be applied in practice. Profitability and unprofitability, prospects or hopelessness of certain decisions are predicted. Phenomena of conflict deformation in personal orientation are recklessness and hasty decision making, poor psychological feeling, inability to understand the people, their relationships, poor discipline. The students develop strategic plans of a large-scale nature, but in the perspective of their implementation there is no structure and orderliness of decisions. They are so preoccupied with the solution of this project, reflected in their minds that the amount of workload exceeds their capabilities and skills.

Guided by the method of K. N. Thomas, which is designed to identify typical ways of responding to a conflict situation, we determine the tendency of the above sociotypes to rivalry and cooperation, the desire for compromise, avoidance of conflict and flexibility in decision making.

Strategic behavior in the implementation of the conflict in the form of rivalry is supported by representatives of the sociotype "Kommersant" (ESFJ) - 14\% (13 people). They are impressed by the style of competition (rivalry) in which they show their activity, independence and autonomy in achieving their own goals. They are not interested in cooperating with others and focus only on their own well-being, using all their potential and abilities. The volitional qualities inherent in this group of people are aimed at satisfying their own interests against the interests of others, forcing them to make only the solutions they need. Only a small percentage (7\% 6 people) seek cooperation for mutual benefit in the team.

The style of avoidance is typical for students whose sociotype is reflected in the "Conservative" typology (ISFJ) $10 \%$ (11 people) and due to the fact that the individual does not defend their rights, does not cooperate with anyone to discuss a decision or evade conflict. To do this, use the problem (leaving the room, changing the topic), ignoring it, shift- 
ing responsibility for the solution to others, postponing the decision.

Imitation of the style of cooperation is mainly characteristic of the sociotype "Journalist" ENFP - 15\% (17 people). They are actively involved in resolving the conflict and defending their interests, but at the same time try to cooperate with other people. This style is characterized by the relative duration of the time parameter, because first the needs, aspirations and interests of both parties are put forward and then they are discussed. Collegiate decision making as a way to satisfy the interests of both parties, is aimed at differentiating the causes of the conflict and establishing the new alternatives in resolving it. The collaboration is the most difficult among other styles but effective style of conflict resolution.

In the process of using the style of compromise with such a sociotype as "Philosopher" INFP - 8\% (9 people) met the interests of both parties by mutual agreements. Unlike cooperation, a compromise is reached on a more generalized level: the parties are equally inferior in their own interests. In the case of a compromise, there is no search for hidden goals, only objective information on the implementation of the conflict is considered. In these cases, the causes of the conflict are not discussed.

Adaptation is a style of acting together with another person, in case of conflict, without trying to defend one's own interests. According to this principle, we note the smallest group of students (10\% - 8 people), who belong to the above sociotypes and are characterized by stereotyped thinking and inability to self-determination in group identification. Unlike avoidance, this style is due to a lack of conviction or reluctance to solve a problem.

\section{Discussion}

Personality as emphasized in the study is influenced by intercultural and interpersonal relationships. The prevailing cultural norms and values in society through the system of educational institutions and the media influence the formation of the individual's psyche, worldview and social attitudes. The psyche of the individual is also influenced by the psychology of the social group to which it belongs: family, school, friends, acquaintances, and so on. Positive or negative experience, relationships with other members of the social group form an appropriate system of internal attitudes of the individual, namely in relation to society, work, people, their own qualities. At the same time, the individual as a conscious individual chooses one or another way of life (Kennedy, 2020).

The problem in a conflict situation is always an obstacle to the realization of the goal, which is associated not only with human interests, but also his/her fears and anxieties. Obstacle, blocking the realization of needs and interests in the conflict is always associated with communication, because it is the activities of another or others are often perceived by the student as a dissonance of the individual and his/her environment. At the heart of the conflict is the presence of contradictions, differences caused by different experiences, differences in human behavior, character traits and other factors of interpersonal interaction (Ireland, Hawdon, Huang, \& Peguero,
2020).

The study noted allow a number of psychological factors that contribute to and enhance the degree of distortion of the perception of conflict (Horton, 2019): stress significantly changes the course of mental processes, can complicate thinking, simplify and modify perception; personal qualities that hinder the adequacy and flexibility of perception of the conflict situation: rigidity, aggression, envy, greed, etc.; excessive levels of negative emotions which can cause distortions in perception, especially traumatic situations; dominance of aggressive behavior and aggression in a life position; high degree of experience, especially in crisis periods of life, which affects the adequacy and flexibility of perceptual processes; state of dependence (alcohol or drugs) and interdependence; the level of awareness of participants about each other; negative attitude towards another participant (due to purposeful and interested manipulation of hidden participants of the conflict); low cognitive level of development of conflict participants, increased suggestibility and lack of independence, uncritical thinking, low level of self-regulation, which affects the level of criticality and adequacy of perception and the characteristics of cognitive processes; increased significance of the problem and the outcome of the conflict for the participants (increased interest in the results of resolving the conflict); specific personality traits - rigidity, aggression, envy, greed, etc.

\section{Conclusions}

The article presents a study of sociotypes of the structural organization of increased conflict of personality and the definition of its dominant type of behavior in a situation of discomfort. The presence of the following sociotypes is shown: ESFJ "Kommersant", ENFP "Journalist", INFP "Philosopher", ISFJ "Conservative", which highlight a number of psychological factors that cause and exacerbate the degree of distortion of human perception of conflict. The causal dysfunctions in the implementation of conflict situations include: rigidity, aggression, envy, greed, excessive levels of negative emotions, which can cause distortions in perception, especially traumatic situations, the dominance of aggressive behavior and aggression in life, a high degree of experience, especially in crisis periods of life and low cognitive level of development of conflict participants, increased suggestibility and independence, uncritical thinking, intellectual disability, etc.

Thus, in addition to these reasons, the personal characteristics of people are quite often incorrectly identified in conflict situations, which leads to increased stress. Practice shows that only objective conflict management leads to positive dynamics in the team and the main criterion is the ability to reach a compromise based on the understanding that contradictions are a criterion of development that can lead to full cooperation. We see the direction of further work in creating a system of psychological support / prevention / correction of increased conflict using the information obtained about the psychological resources of students. 


\section{References}

1. Hong, J., Choi, J., Espelage, D., BoragginaBallard, L., \& Fisher, B. (2020). Are Children of Welfare Recipients at a Heightened Risk of Bullying and Peer Victimization? Child \& Youth Care Forum. DOI: https://doi.org/10.1007/s10566-020-09587-w [in English].

2. Horton, P. (2019). School Bullying and Bare

Life: Challenging the State of Exception. Educational Philosophy and Theory, 51 (14), 1444-1453. DOI: https://doi.org/10.1080 / 00131857.2018.1557043 [in English].

3. Ireland, L., Hawdon, J., Huang, B., \& Peguero, A. (2020). Preconditions for Guardianship Interventions in Cyberbullying: Incident Interpretation, Collective and Automated Efficacy, and Relative Popularity of Bullies. Computers in Human Behavior, 113, 106-506.
DOI: https://doi.org/10.1016 / j.chb.2020.106506 [in English].

4. Kennedy, R. (2020). A Meta-Analysis of the Outcomes of Bullying Prevention Programs on Subtypes of Traditional Bullying Victimization: Verbal, Relational, and Physical. Aggression and Violent Behavior, 55, 101485. DOI: https://doi.org/10.1016 / j.avb.2020.101485 [in English].

5. Kramarenko, N. (2016). Cyberbullying: The meeting place cannot be avoided. Magazine for parents "Grapes", 3 (71), May-June. Retrieved from https://www.pravmir.ru/kiberbulling-mesta-vstrechi-izbezhat-nelzya/ [in English].

6. Viznyuk, I. (2020). Psychosomatic correlates in the aspect of development of hypochondriac behavior of the personality. Kyiv. Psychological Journal, 8(7), 174-188. DOI: https://doi.org/10.31108/1.2019.5.8.11 [in English].

Сергій Долинний,

аспірант кафедри психологї та сочиіальної роботи, Вінницький державний педагогічний університет імені Михайла Коиюбинського, вул. Острозького, 32, Вінниия, Украӥна

\section{ПСИХОЛОГІЯ ОСОБИСТОСТІ В КОНТЕКСТІ КОНФЛІКТНИХ ІНТЕРПРЕТАЦЙ}

У статті аналізуються найбільш важливі психологічні передумови конфліктної ситуації, на основі яких формується стратегія й тактика поведінки людей у разі розбіжностей їх інтересів. Основні психологічні моделі конфлікту подані у дослідженні, за допомогою яких інтерпретовано соціотипи, які в ракурсі сучасності виокреслюють психологічний портрет особистості. Метою дослідження є обгрунтування причинно-наслідкових дисфункцій у реалізації конфліктних ситуацій та висвітлення ідей щодо уникнення конфлікту особистістю. У дослідженні використано опитувальник Кейрсі для оцінки темпераменту респондентів і методика К. Н. Томаса для визначення їх типових способів реагування на конфліктну ситуацію, в результаті чого визначено схильність соціотипів до суперництва та співробітництва, прагнення до компромісів, уникнення конфліктів та поступливості в прийнятті рішень. У статті обгрунтовано концепцію типів особистості та їх взаємодію у структурі міжособистісних відносин. За методикою Д. Кейрсі, яка орієнтована на типології К. Юнга і теорії інформаційного метаболізму А. Кемпинського, існують 16 типів інформаційного обміну між суб'єктами. Проблемою визначення особистості у безперервному потоці інформаційних сенсацій, комунікативних перцепцій, інноваційних компетенцій, різноманіття моделей світопізнання є формування чуттєвого образу людини як інформативного суб'єкта, адекватного у соціометричному вимірі. Керуючись методикою К. Томаса, яка призначена для виявлення типових способів реагування на конфліктну ситуацію, визначаємо схильність вищевказаних соціотипів до суперництва та співробітництва, прагнення до компромісів, уникнення конфліктів та поступливості у прийнятті рішень. У вимірі соціонічної моделі суб'єктами інформаційних взаємовпливів здійснюється адекватна оцінка власного потенціалу, пошуку відповідних шляхів самореалізації, конкурентоспроможності, а також в об'єктивному сприйнятті можливостей і здібностей оточуючих задля побудови гармонічних стосунків із ними. Концептуальне значення особистості охоплює широкий спектр внутрішніх психічних процесів, що обумовлюють особливості поводження людини в різних ситуаціях. Лише об'єктивне управління конфліктом призводить до отримання позитивної динаміки в разі зіткнення інтересів, при цьому основним критерієм є можливість досягнення компромісу, заснованого на розумінні, що суперечності - $є$ критерієм розвитку, який може привести до повноцінного співробітництва.

Ключові слова: соціотип, особистість, конфліктна ситуація, управління конфліктами, соціальна група, фактори міжособистісної взаємодії. 